\title{
Pengaruh Undang-Undang Akuntan Publik terhadap Minat Mahasiswa Akuntansi sebagai Akuntan Publik (Studi Kasus IIB Darmajaya)
}

\author{
Reva Meiliana \\ reva_meiliana@yahoo.com \\ Program Studi Akuntansi, Informatics and Business Institute Darmajaya \\ Jl. Z.A. PagarAlam No. 93 Labuhan Ratu Bandar Lampung Indonesia 35142 \\ Rieka Ramadhaniyah \\ rramadhaniyah@yahoo.co.id \\ Program Studi Akuntansi, Informatics and Business Institute Darmajaya \\ Jl. Z.A. PagarAlam No. 93 Labuhan Ratu Bandar Lampung Indonesia 35142
}

\begin{abstract}
The purpose of this research is to examine the effect of Public Accountant according to Undang-Undang number 5 year 2011 about the regulation of Public Accountant in Indonesia towards the interest of Accounting students to become Public Accountant. The objects of this study are Accounting Students have graduated in Auditing in IIB Darmajaya. Kuesionaer that can be used to study as many as 184 pieces or can be said to be a response rate of $62 \%$. Furthermore, the primary data that has been collected is processed and analyzed by using descriptive statistical analysis. Testing hypotheses were tested by using linear regression. The results showed empirical evidence that the Public Accounting Law have affected the interest became public accountant.
\end{abstract}

Keywords: Undang-Undang Akuntan Publik, Public Accountant

\begin{abstract}
Abstrak
Tujuan penelitian ini adalah untuk membuktikan apakah Undang-Undang Akuntan Publik nomor 5 tahun 2011 Berpengaruh Terhadap Minat Mahasiswa Akuntansi Sebagai Akuntan Publik pada mahasiswa IBI Darmajaya. Populasi penelitian adalah mahasiswa Program Studi Akuntansi IIB Darmajaya yang sudah lulus mata kuliah Auditing. Kuesioner yang dapat digunakan untuk diteliti sebanyak 184 buah atau dapat dikatakan respon rate sebesar $62 \%$. Selanjutnya data primer yang telah dikumpulkan diolah dan dianalisis menggunakan analisis statistik deskriptif. Pengujian hipotesis diuji dengan menggunakan regresi linier. Hasil penelitian menunjukkan bukti empiris bahwa Undang-Undang Akuntan Publik berpengaruh terhadap minat menjadi akuntan publik.
\end{abstract}

Kata Kunci: Undang - Undang Akuntan Publik, Akuntan Publik 


\section{PENDAHULUAN}

Profesi Akuntan publik merupakan profesi yang sangat dibutuhkan saat ini oleh dunia ekonomi dan usaha. Kebutuhan pengguna jasa akuntan publik akan semakin meningkat, terutama kebutuhan atas kualitas informasi keuangan yang digunakan sebagai salah satu pertimbangan dalam pengambilan keputusan.

Profesi Akuntan Publik mengemban kepercayaan masyarakat dalam memberikan opini atas kewajaran laporan keuangan suatu entitas. Sehingga akuntan publik dituntut untuk meningkatkan kompetensi dan profesionalisme agar dapat memenuhi kebutuhan pengguna jasa dan mengemban kepercayaan publik.

Undang-undang Akuntan Publik No 5 Tahun 2011 dengan tujuan melindungi kepentingan publik, kepentingan profesi Akuntan Publik serta landasan hukum yang paling kuat bagi regulator, Profesi Akuntan Publik dan masyarkat. Tetapi terdapat salah satu penjelasan yang menjadi pro dan kontra, yakni Penjelasan pasal 6 ayat 1 huruf a yang berbunyi “....yang dapat mengikuti pendidikan profesi akuntan publik adalah seseorang yang memiliki pendidikan minimal sarjana strata 1 (S-1), diploma IV (D-IV), atau yang setara". Penjelasan pasal tersebut berarti untuk menjadi seorang akuntan publik lulusan yang berasal dari jurusan akuntansi mampu bersaing dengan lulusan jurusan non-akuntansi sehingga akan berdampak pada permintaan jasa akuntan yang semakin menurun.

Mahasiswa yang kontra (menolak) adanya penerapan UU No. 5 Tahun 2011 tentang Akuntan Publik memiliki persepsi bahwa nantinya kualitas dari Akuntan publik akan dipertanyakan apabila yang berhak mengikuti pendidikan profesi akuntan publik tidak hanya dari lulusan jurusan akuntansi. Sedangkan Mahasiswa yang netral menyikapi adanya UU No 5 tahun 2011 tentang Akuntan Publik dengan biasa saja, tanpa adanya rasa kekhawatiran. Mahasiswa yang netral menyikapi dengan tetap melakukan berbagai kegiatan guna menunjang pencapaian karir

Pengenalan atas profesi tersebut dilakukan pada tahun ke-2 sampai dengan tahun ke-4. Sehingga mahasiswa melakukan pencarian dan seleksi karir apa yang akan dipilih kelak ketika sudah lulus. Masa-masa di perguruan tinggi adalah masa ketika mahasiswa secara aktif melakukan eksplorasi karir dan mencari pengalaman serta pendidikan yang mereka perlukan untuk menjalankan karir yang telah didapat informasinya tersebut.

Setiap tahun dihasilkan tenaga terdidik bidang akuntansi. Salah satunya berasal dari kampus IIB Darmajaya.

Tabel 1. Jumlah Mahasiswa Jurusan Akuntansi IIB Darmajaya

\begin{tabular}{|c|c|}
\hline Tahun & Jumlah Mahasiswa \\
\hline $2013 / 2014$ & 157 \\
\hline $2014 / 2015$ & 169 \\
\hline Jumlah & 298 \\
\hline
\end{tabular}

Sumber : Data Diolah

Pada tabel ini menyajikan jumlah mahasiswa yang berorientasi pada mata kuliah auditing dan telah menyelesaikan matakuliah tersebut. Dari jumlah tersebut yang memahami profesi akuntan publik dan mengenal UU No. 5 Tahun 2011 masih sangat minim. Ironisnya lagi sekitar 7,38\% dari 298 atau hanya 22 orang yang berkenan untuk berpraktik sebagai akuntan publik, sedangkan lainnya lebih memilih berkarir pada profesi lainnya.

Hal tersebut juga didukung oleh data hasil wawancara pada mahasiswa akuntansi S1 IIB Darmajaya yang dilaksanakan pada tanggal 17 September 2016 sampai dengan 17 Oktober 2016 yang menunjukan bahwa hanya beberapa mahasiswa yang paham akan profesi akuntan public dan mengetahui adanya UU No. 5 Tahun 2011. Data tersebut diperoleh dari mahasiswa 
semester 4 dan semester 6 . Ada banyak alasan ketidaktertarikan mahasiswa menjadi akuntan publik yaitu pekerjaan yang penuh tantangan dan resiko, banyak pilihan karir lain yang mudah dicapai, dan tidak yakin dengan kemampuan yang dimiliki. Selain itu, sebagian mahasiswa mempunyai sikap apatis pada profesi akuntan publik.

Undang-undang No 5 tahun 2011 akan menjadi sebuah tantangan bagi mahasiswa akuntansi untuk dapat bersaing dengan jurusan non-akuntansi untuk menjadi seorang akuntan publik. Fenomena ini amat menarik untuk dikaji lebih lanjut dampak penerapan Undangundang No 5 tahun 2011 terhadap motivasi, optimisme dan perencanaan karir mahasiswa. Ada beberapa permasalah yang perlu dikaji lebih lanjut yaitu pertama, Apakah terdapat pengaruh penerapan Undang-undang akuntan publik nomor 5 tahun 2011 terhadap minat mahasiswa akuntansi sebagai akuntan publik. Pemberlakuan Undang-undang Nomor 5 tahun 2011 secara tidak langsung akan mempengaruhi motivasi mahasiwa akuntansi baik motivasi karir, dan motivasi ekonomi. Berdasarkan latar belakang tersebut, sehingga permasalahan yang akan dikaji dalam penelitian ini adalah bagaimana Pengaruh Undang-Undang Akuntan Publik Terhadap Minat Mahasiswa Akuntansi Sebagai Akuntan Publik. Rumusan masalah dalam penelitian ini Apakah Undang-Undang akuntan publik berpengaruh terhadap minat mahasiswa sebagai akuntan publik. Tujuan yang ingin dicapai dari penelitian ini adalah untuk membuktikan: Apakah Undang-Undang Akuntan Publik berpengaruh terhadap minat mahasiwa sebagai akuntan publik.

\section{KAJIAN TEORI}

\section{Teori Pengharapan}

Motivasi adalah "...... getting a person to exert a high degree of effort ...." yang artinya motivasi membuat seseorang bekerja lebih berprestasi (Matutina.et al, 1993). Dengan demikian dapat dikatakan bahwa motivasi pada dasarnya adalah kondisi mental yang mendorong dilakukannya suatu tindakan (action atau activities) dan memberikan kekuatan yang mengarah kepada pencapaian kebutuhan, memberi kepuasan ataupun mengurangi ketidakseimbangan. Ada definisi yang menyatakan bahwa motivasi berhubungan dengan:

1. Pengaruh perilaku.

2. Kekuatan reaksi (maksudnya upaya kerja), setelah seseorang karyawan telah memutuskan arah tindakan-tindakan.

3. Persistensi perilaku, atau berapa lama orang yang bersangkutan melanjutkan pelaksanaan perilaku dengan cara tertentu (Campell et al, 1970)

Teori Pengharapan (expectancy theory) pada dasarnya merupakan fungsi dari tiga karakteristik (Cokroaminoto, 2007), yaitu :

1. Persepsi pegawai bahwa upayanya mengarah pada suatu kinerja.

2. Persepsi pegawai bahwa kinerjanya dihargai (misalnya dengan gaji atau pujian).

3. Nilai yang diberikan pegawai terhadap imbalan yang diberikan

Teori Vroom's Expectancy menyatakan perilaku yang diharapkan dalam pekerjaan akan meningkat jika seseorang merasakan adanya hubungan yang positif antara usaha-usaha yang dilakukannya dengan kinerja (Simamora, 2006). Perilaku-perilaku tersebut selanjutnya meningkat jika ada hubungan positif antara kinerja yang baik dengan imbalan yang mereka terima, terutama imbalan yang bernilai bagi dirinya (Nelson, 2008).

Secara singkat, kunci dari teori pengharapan adalah pemahaman sasaran individu dan keterkaitan antara upaya dan kinerja, antara kinerja dan imbalan. Oleh karena itu pemilihan karir mahasiswa akuntansi ditentukan oleh pengharapan akan karir yang akan mereka pilih apakah karir tersebut dianggap dapat memenuhi kebutuhan individu mereka dan apakah karir tersebut mempunyai daya tarik bagi mereka. 
Teori harapan merupakan teori yang paling baik dipandang menjelaskan motivasi seseorang dalam kehidupan organisasinya, walaupun teori motivasi memiliki kelemahan dan kelebihan. Kuatnya kecenderungan seseorang bertindak dengan cara tertentu bergantung pada kekuatan harapan bahwa tindakan tersebut akan diikuti oleh suatu hasil tertentu dan pada daya tarik dari hasil itu bagi orang yang bersangkutan. Teori ini memiliki 3 variabel yang mendukungnya daya tarik, hubungan antara prestasi kerja dengan imbalan serta hubungan antara usaha dan prestasi kerja. Daya tarik yaitu sepenting apa hasil atau imbalan yang diperoleh dalam penyelesaian tugasnya. Artinya, sejauh mana hasil yang diperoleh dalam bentuk imbalan memainkan peranan dalam pemuasan kebutuhannya.

\section{Auditing}

Auditing adalah suatu proses sistematik untuk memperoleh dan mengevaluasi bukti secara objektif mengenai pernyataan-pernyataan tentang kegiatan dan kejadian ekonomi dengan tujuan untuk menetapkan tingkat kesesuaian antara pernyataan-pernyataan tersebut dengan kriteria yang telah ditetapkan, serta penyampaian hasil-hasilnya kepada pemakai yang berkepentingan (Mulyadi, 2013).

Auditing is the accumulation and evaluation of evidence about information to determine and report on the degree of correspondence between the information and established criteria. Auditing should be done by a competent, independent person" (Arens, 2013).

Berdasarkan beberapa pengertian auditing di atas maka audit mengandung unsur-unsur (Arens, 2013):

1. Suatu proses sistematis, artinya audit merupakan suatu langkah atau prosedur yang logis, berkerangka dan terorganisasi. Auditing dilakukan dengan suatu urutan langkah yang direncanakan, terorganisasi dan bertujuan.

2. Untuk memperoleh dan mengevaluasi bukti secara objektif, artinya proses sistematik ditujukan untuk memperoleh bukti yang mendasari pernyataan yang dibuat oleh individu atau badan usaha serta untuk mengevaluasi tanpa memihak atau berprasangka terhadap bukti-bukti tersebut.

3. Pernyataan mengenai kegiatan dan kejadian ekonomi, artinya pernyataan mengenai kegiatan dan kejadian ekonomi merupakan hasil proses akuntansi.

4. Menetapkan tingkat kesesuaian, artinya pengumpulan bukti mengenai pernyataan dan evaluasi terhadap hasil pengumpulan bukti tersebut dimaksudkan untuk menetapkan kesesuaian pernyataan tersebut dengan kriteria yang telah ditetapkan. Tingkat kesesuaian antara pernyataan dengan kriteria tersebut kemungkinan dapat dikuantifikasikan, kemungkinan pula bersifat kualitatif.

5. Kriteria yang telah ditetapkan, artinya kriteria atau standar yang dipakai sebagai dasar untuk menilai pernyataan (berupa hasil akuntansi) dapat berupa:

a. peraturan yang ditetapkan oleh suatu badan legislatif.

b. anggaran atau ukuran prestasi yang ditetapkan oleh manajemen.

c. prinsip akuntansi berterima umum (PABU) diindonesia.

6. Penyampaian hasil (atestasi), dimana penyampaian hasil dilakukan secara tertulis dalam bentuk laporan audit (audit report).

7. Pemakai yang berkepentingan, pemakai yang berkepentingan terhadap laporan audit adalah para pemakai informasi keuangan, misalnya pemegang saham, manajemen, kreditur, calon investor, organisasi buruh dan kantor pelayanan pajak.

\section{Akuntan Publik}

Akuntan Publik adalah akuntan yang telah memperoleh izin dari Menteri Keuangan untuk memberikan jasa akuntan publikdi Indonesia. Ketentuan mengenai Akuntan Publik di Indonesia diatur dalam Peraturan Menteri Keuangan Nomor 17/PMK.01/2008. Setiap Akuntan 
Publik wajib menjadi anggota Institut Akuntan Publik Indonesia (IAPI), asosiasi profesi yang diakui oleh Pemerintah. Beberapa jenis pekerjaan yang dapat dijabat oleh seorang akuntan yaitu:

1. Akuntan Pemerintah.

Akuntan Pemerintah adalah akuntan yang bekerja pada badan-badanpemerintah, seperti Badan Pengawas Keuangan dan Pembangungan (BPKP),Badan Pemeriksa Keuangan (BPK), dan Dirjen Pajak.

2. Akuntan Pendidik.

Akuntan Pendidik adalah akuntan yang bekerja dalam pendidikan akuntansi, yaitu mengajar, menyusun kurikulum pendidikan akuntansi dan melakukan penelitian di bidang akuntasi.

3. Akuntan Perusahaan.

Akuntan Perusahaan adalah akuntan yang bekerja dalam suatuperusahaan. Tugas-tugas yang dikerjakan oleh akuntan perusahaan dapat berupa penyusunan sistem akuntansi, penyusunan laporan keuangan kepada pihak-pihak diluar perusahaan, penyusunan anggaran perusahaan, penyusunan laporan akuntansi kepada manajemen, menangani masalah perusahaan dalam bidang keuangan dan melakukan pemeriksaan intern.

4. Akuntan Publik.

Menurut UU No. 5 tahun 2011 tentang Akuntan Publik "Akuntan Publik adalah seseorang yang telah memperoleh izin untuk memberikan jasa sebagaimana diatur dalam Undang-Undang ini." Menurut Peraturan Menteri Keuangan nomor 17/PMK.01/2008 tentang Jasa Akuntan Publik:“Akuntan adalah seseorang yang berhak menyandang gelar atau sebutan akuntan sesuai dengan peraturan perundang-undangan yang berlaku. Akuntan Publik adalah akuntan yang telah memperoleh izin dari Menteri untuk memberikan jasa.”. Akuntan Publik yang profesional adalah akuntan publik yang menjunjung tinggi integritas, objektivitas dan independensi (IAPI, 2013).

Berikut ini merupakan gambaran jenjang karir akuntan publik (Mulyadi, 2013):

1. Auditor Junior, bertugas melaksanakan prosedur audit secara rinci,membuat kertas kerja untuk mendokumentasikan pekerjaan audit yang telah dilaksanakan.

2. Auditor senior, bertugas untuk melaksanakan audit dan bertanggungjawab untuk mengusahakan biaya audit dan waktu audit sesuai dengan rencana, mengarahkan dan mereviu pekerjaan auditor junior.

3. Manajer, merupakan pengawas audit yang bertugas membantu auditor senior dalam merencanakan program audit dan waktu audit; mereview kertas kerja, laporan audit dan management letter.

4. Partner, bertanggung jawab atas hubungan dengan klien, dan bertanggungjawab secara keseluruhan mengenai auditing.

\section{Profesi Akuntan Publik}

Profesi akuntan publik menghasilkan berbagai jasa bagi masyarakat, yaitu jasa assurance, jasa atestasi, dan jasa non assurance. Jasa assurance adalah jasa profesional independen yang meningkatkan mutu informasi bagi pengambil keputusan. Jasa atestasi terdiri dari audit, pemeriksaan (examination), review, dan prosedur yang disepakati (agreed upon procedure). Jasa atestasi adalah suatu pernyataan pendapat, pertimbangan orang yang independen dan kompeten tentang apakah asersi suatu entitas sesuai dalam semua hal yang material, dengan kriteria yang telah ditetapkan. Jasa non assurance adalah jasa yang dihasilkan oleh akuntan publik yang di dalamnya ia tidak memberikan suatu pendapat, keyakinan negatif, ringkasan temuan, atau bentuk lain keyakinan. Contoh jasa non assurance yang dihasilkan oleh profesi akuntan publik adalah jasa kompilasi, jasa perpajakan, jasa konsultasi (Arens, 2013). 
Dalam memenuhi tanggung jawabnya sebagai profesional, Akuntan publik wajib memiliki Kantor Akuntan Publik (KAP) sebagai suatu wadah. Diatur Oleh Keputusan Menteri Keuangan Republik Indonesia Nomor: 423/KMK.06/2002 pasal 5 yang menyatakan:

1. Akuntan Publik wajib mempunyai KAP untuk dapat memberikan jasanya.

2. Kewajiban sebagaimana dimaksud dalam ayat (1) harus dipenuhi paling lambat 6 (enam) bulan sejak izin Akuntan Publik diterbitkan.

3. Akuntan Publik yang mengundurkan diri dari KAP wajib mempunyai KAP paling lambat 6 (enam) bulan sejak pengunduran diri.

4. Dalam hal kewajiban Direktur Jenderal atas nama Menteri mengenakan sanksi pencabutan izin terhadap Akuntan Publik yang bersangkutan.

Berdasarkan Undang-Undang nomor 5 Tahun 2011 tentang Akuntan Publik "Kantor Akuntan Publik, yang selanjutnya disingkat KAP, adalah badan usaha yang didirikan berdasarkan ketentuan peraturan perundang-undangan dan mendapatkan izin usaha berdasarkan Undang-Undang ini.". Akuntan Publik dapat diartikan sebagai seseorang yang terhimpun dalam Kantor Akuntan Publik (KAP) dan telah memenuhi persyaratan untuk menjadi Akuntan Publik, termasuk lulus dalam Ujian Sertifikasi Akuntan Publik serta telah memperoleh izin untuk memberikan jasa dIIBdang akuntansi khususnya bidang penilaian. Seorang Akuntan Publik mempunyai tanggung jawab utama dalam melakukan fungsi audit atas laporan keuangan historis sebuah entitas komersial maupunnon komersial dan memberikan penilaian kewajaran atas suatu laporan keuangan tersebut.

\section{Undang Undang Akuntan Publik}

Undang-Undang Nomor 5 Tahun 2011 merupakan aturan-aturan dan ketentuan-ketentuan yang dibuat oleh Menteri Keuangan Republik Indonesiadan telah disahkan oleh Dewan Perwakilan Rakyat (DPR) Republik Indonesia dan ditandatangi oleh Presiden Republik Indonesia, yang mengatur tentang akuntan publik. Undang-Undang akuntan publik dibuatuntuk memberi perlindungan hukum baik bagi para akuntan publik maupun pengguna jasa Akuntan Publik di Indonesia.

Undang-Undang tentang Akuntan Publik yang mengatur berbagai hal mendasar dalam profesi Akuntan Publik, dengan tujuan untuk:

1. Melindungi kepentingan publik;

2. Mendukung perekonomian yang sehat, efisien, dan transparan;

3. Memelihara integritas profesi Akuntan Publik;

4. Meningkatkan kompetensi dan kualitas profesi Akuntan Publik;

5. Melindungi kepentingan profesi Akuntan Publik sesuai dengan standar; dan

6. Kode etik profesi.

Undang-Undang ini mengatur antara lain:

1. Lingkup jasa Akuntan Publik.

2. Perizinan Akuntan Publik dan KAP;

3. Hak, kewajiban, dan larangan bagi Akuntan Publik dan KAP;

4. Kerja sama antar-Kantor Akuntan Publik (OAI) dan kerja sama antaraKAP dan Kantor Akuntan Publik Asing (KAPA) atau Organisasi Audit Asing (OAA);

5. Asosiasi Profesi Akuntan Publik;

6. Komite Profesi Akuntan Publik;

7. Pembinaan dan pengawasan oleh Menteri;

8. Sanksi Administratif; dan

9. Ketentuan pidana.

Di samping mengatur profesi Akuntan Publik, Undang-Undang ini juga mengatur KAP yang merupakan wadah bagi Akuntan Publik dalam memberikan jasa profesional. Hal yang mendasar mengenai pengaturan KAP antara lain mengenai perizinan KAP dan bentuk usaha 
KAP. Salah satu persyaratan izin usaha KAP adalah memiliki rancangan sistem pengendalian mutu sehinga dapat menjamin bahwa perikatan profesional dilaksanakan sesuai dengan SPAP. Sementera itu, pengaturan mengenai bentuk usaha KAP dimaksudkan agar sesuai dengan karakteristik profesi Akuntan Publik, yaitu independensi dan tanggung jawab profesionalAkuntan Publik terhadap hasil pekerjaannya.

\section{Penelitian Terdahulu}

Berikut ini merupakan hasil penelitian terkait dengan pilihan profesi Akuntan Publik:

1. Penelitian Ikhsan, et.al (2013) tentang Dampak Implementasi Undang-Undang Akuntan Publik Terhadap Minat Menjadi Akuntan Publik Studi Kasus Mahasiswa Akuntansi Universitas Negeri Semarang. Hasil penelitian menunjukkan bukti empiris bahwa implementasi UU Akuntan Publik berpengaruh positif terhadap minat menjadi akuntan publik. Namun demikian pengaruh tersebut sangat kecil, hal tersebut ditengarahi oleh pemahaman responden terhadap UU Akuntan Publik yang masih minim.

2. Penelitian Kurnia (2014) tentang Undang-undang No.5 Tahun 2011 tentang Akuntan Publik dan Dampaknya terhadap minat Mahasiswa menjadi Akuntan Publik di Universitas Multimedia Nusantara, Universitas Bina Nusantara, Prasetya Mulya Business School, dan Universitas Pelita Harapan. Kesimpulan penelitian adalah sanksi Akuntan Publik memiliki pengaruh positif terhadap minat mahasiswa Akutansi untuk menjadi Akuntan Publik dan persyaratan, dan kewajiban Akuntan Publik secara parsial tidak memiliki pengaruh yang signifikan terhadap minat mahasiswa Akuntansi untuk menjadi Akuntan Publik.

\section{Kerangka Berpikir}

Dari uraian dan penjelasan yang telah dipaparkan, maka dalam penelitian ini membahas Undang-Undang akuntan publik dan pilihan karir mahasiswa akuntansi sebagai akuntan publik.

Pengetahuan Undang-Undang No.5 tahun 2011 tentang Akuntan Publik adalah segala sesuatu yang diketahui oleh mahasiswa prodi akuntansi mengenai hal yang terkait dengan Undang-Undang No.5 tahun 2011 tentang Akuntan Publik Jika mahasiswa memiliki pengetahuan tentang Akuntan Publik yang terdapat pada Undang-Undang No.5 tahun 2011 tentang Akuntan Publik, maka kemungkinan mahasiswa tersebut memiliki minat untuk mengikuti pendidikan profesi akuntansi karena untuk menjadi akuntan publik harus seorang mahasiswa menempuh pendidikan akuntansi profesi.

Penelitian Kurnia (2014) menunjukkan bahwa Hasil dari penelitian ini adalah (1) sanksi Akuntan Publik memiliki pengaruh positif terhadap minat mahasiswa Akutansi untuk menjadi Akuntan Publik (2) persyaratan, dan kewajiban Akuntan Publik secara parsial tidak memiliki pengaruh yang signifikan terhadap minat mahasiswa Akuntansi untuk menjadi Akuntan Publik (3) Persyataran, kewajiban, dan sanksi Akuntan Publik secara simultan memiliki pengaruh yang signifikan terhadap minat mahasiswa Akuntansi untuk menjadi Akuntan Publik.

Berdasarkan uraian diatas maka dapat disimpulkan sebagai berikut: Diduga Pengetahuan Undang-Undang No.5 tahun 2011 tentang Akuntan Publik mempengaruhi terhadap minat mahasiswa Akuntansi Sebagai Akuntan Publik. 


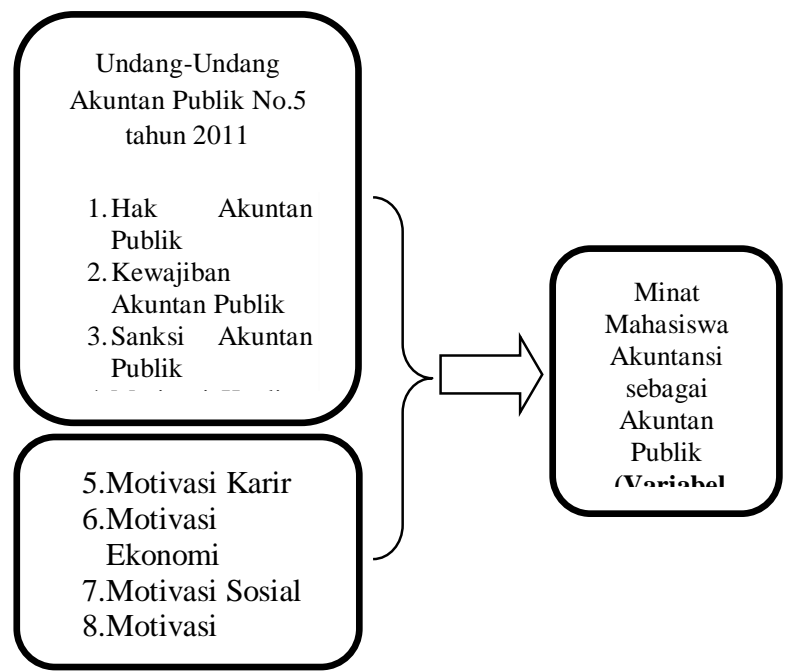

\section{METODE PENELITIAN}

\section{Jenis Penelitian}

Jenis penelitian yang digunakan dalam penelitian ini adalah penelitian kausal komparatif. Penelitian kausal komparatif merupakan tipe penelitian dengan karakteristik masalah berupa hubungan sebab-akibat antara dua variabel atau lebih. Peneliti melakukan pengamatan terhadap konsekuensi-konsekuensi yang timbul dan menelusuri kembali fakta yang secara masuk akal sebagai faktor-faktor penyebabnya.

\section{Populasi dan Sampel}

Objek penelitian adalah mahasiswa Program Studi Akuntansi IIB Darmajaya konsentrasi Pemeriksaan Akuntansi (Auditing) yang minimal sudah mencapai semester 4 dan 6 dan pernah mengambil mata kuliah Pemeriksaan Akuntansi. Penelitian ini menggunakan data primer, yaitu data yang diperoleh langsung dari sumber data dengan menggunakan kuesioner yang disebarkan kepada mahasiswa Program Studi Akuntansi secara langsung.

\section{Definisi Konseptual dan Operasional variabel Variabel Dependen}

Variabel dependen sering disebut dengan variabel terikat yaitu variabel yang disebabkan / dipengaruhi oleh adanya variabel bebas/ variabel independen. Variabel Dependen dalam penelitian ini adalah minat menjadi Akuntan Publik yaitu keinginan atau kesukaan yang tinggi untuk memperoleh izin dan memberikan jasa Akuntan Publik yang memiliki gelar CPA dan berhak membuka praktik jasa akuntan. Variabel ini menggunakan kuesioner Putro (2012) yang terdiri dari 8 butir pertanyaan. Skala pengukuran yang digunakan adalah skala interval dengan skala likert dengan pemberian skor : (1) Sangat Tidak Setuju; (2) Tidak Setuju; (3) Netral (4) Setuju dan (5) Sangat Setuju.

\section{Variabel Independen}

Variabel independen Merupakan variabel yang mempengaruhi atau yang menjadi sebab perubahannya atau timbulnya variabel dependen (terikat). Variabel independen dalam penelitian ini, meliputi:

1. Hak Akuntan Publik, diukur dengan menggunakan kuesioner yang dibuat oleh peneliti dengan mengacu pada UU No. 5 Tahun 2011 tentang Akuntan Publik pasal 25 tentang Hak Akuntan Publik yang terdiri dari 3 butir pertanyaan. 
2. Kewajiban Akuntan Publik, diukur dengan menggunakan kuesioner yang dibuat oleh peneliti dengan mengacu pada UU No. 5 Tahun 2011 tentang Akuntan Publik pasal 25 tentang kewajiban Akuntan Publik yang terdiri dari 3 butir pertanyaan.

3. Sanksi Akuntan Publik, diukur dengan menggunakan kuesioner yang dibuat oleh peneliti dengan mengacu pada UU No. 5 Tahun 2011 tentang Akuntan Publik pasal 53, 55-58 tentang sanksi administratif dan/atau sanksi pidana yang akan dikenakan kepada Akuntan Publik apabila Akuntan Publik yang bersangkutan melanggar ketentuan tertentu yang terdiri dari 4 butir pertanyaan.

4. Tentang PMK No.25 Tahun 2014, diukur dengan menggunakan kuesioner yang dibuat oleh peneliti yang terdiri dari 6 butir pertanyaan.

5. Minat/Motivasi menjadi Akuntan Publik motivasi karir, motivasi ekonomi, motivasi kualitas diri, motivasi status sosial dan minat mahasiswa menjadi akuntan publik.

Variabel independen diukur dengan menggunakan skala interval dengan 5 skala likert sebagai berikut: (1) Sangat Tidak Setuju; (2) Tidak Setuju; (3) Netral (4) Setuju dan (5) Sangat Setuju

\section{Metode Pengumpulan Data}

Penelitian ini menggunakan data primer, yaitu data yang diperoleh langsung dari sumber data dengan menggunakan kuesioner yang disebarkan kepada mahasiswa Program Studi Akuntansi secara langsung.

Metode pengambilan data yang digunakan yaitu kuesioner, wawancara, dan studi pustaka. Pengumpulan data yang digunakan dalam penelitian ini adalah a five point likert scale kuesioner dengan jawaban dari sangat tidak setuju sampai dengan sangat setuju sekali, dimana kuesioner tersebut dibagikan secara langsung dan dilakukan secara lisan (wawancara). (Ghozali,2013).

\section{Metode Analisis Data \\ Uji Statistik Deskriptif}

Merupakan analisis yang menggambarkan variabel yang diteliti. Analisis ini digunakan untuk mendeskripsikan persentase masing-masing variabel bebas yaitu variabel UndangUndang Akuntan Publik.

\section{Uji Validitas}

Uji validitas ini digunakan untuk mengukur sah atau valid tidaknya suatu angket atau kuesioner. Suatu kuesioner dapat dikatakan valid jika pertanyaan pada kuesioner mampu untuk mengungkapkan dan mengukur sesuatu yang akan diukur. Uji validitas ini dilakukan dengan membandingkan nilai $\mathrm{r}$ hitung dengan $\mathrm{r}$ tabel untuk tingkat signifikansi 5\% dari degree of freedom $(\mathrm{df})=\mathrm{n}-2$, dalam hal ini $\mathrm{n}$ adalah jumlah sampel. Apabila rhitung $>$ rtabel maka pertanyaan atau indikator tersebut dinyatakan valid, dan sebaliknya jika rhitung < rtabel maka pertanyaan atau indikator tersebut dinyatakan tidak valid.

Hasil uji validitas instrumen variabel Persepsi mahasiswa tentang Undang-Undang Akuntan Publik yang diukur dengan 16 item pernyataan diperoleh hasil bahwa sebanyak 16 butir item pernyataan secara keseluruhan diperoleh nilai r-hitung > r-tabel maka semua pertanyaan atau indikator tersebut dinyatakan valid.

\section{Uji Reliabilitas}

Reliabilitas adalah alat untuk mengukur suatu kuesioner yang merupakan indikator dari variabel atau konstruk. Suatu kuesioner dikatakan reliabel atau handal jika jawaban seseorang terhadap pertanyaan adalah konsisten atau stabil dari waktu ke waktu (Ghozali,2013). 
Untuk mengetahui reliabilitas suatu kuesioner dapat dilihat dari nilai Cronbach Alpha. Kriterianya adalah jika nilai Cronbach Alpha > 0,60 maka pertanyaan-pertanyaan yang digunakan untuk mengukur variabel tersebut adalah "reliabel". Sedangkan jika nilai Cronbach Alpha $<0,60$ maka pertanyaan-pertanyaan yang digunakan untuk mengukur variabel tersebut adalah "tidak reliabel” (Ghozali, 2013).

\section{Uji Normalitas}

Uji normalitas digunakan untuk mengetahui apakah data yang terkumpul menunjukkan distribusi normal atau tidak. Ukurannya adalah jika distribusi data adalah normal, maka garis yang menggambarkan data akan mengikuti garis mendekati data normal atau mendekati normal. Dasar pengambilan keputusan berdasarkan probabilitas. Jika probabilitas lebih besar dari 0,05 maka data dalam penelitian berdistribusi normal (Ghozali, 2013).

\section{Pengujian Hipotesis}

\section{Analisis Regresi Linier Berganda}

Hipotesis dilakukan dengan uji regresi linier berganda dengan persamaan sebagai berikut :

$\mathrm{Y}=\alpha+\beta 1 X 1+\beta 2 \mathrm{X} 2+\beta 3 \mathrm{X3}+\beta 4 \mathrm{X} 4+\beta 5 \mathrm{X} 5+\beta 6 \mathrm{X6}+\beta 7 \mathrm{X} 7++\beta 8 X 8+e$

Keterangan :

$\mathrm{Y}=$ minat menjadi Akuntan Publik

$\alpha=$ konstanta

$\beta 1, \beta 2, \beta 3=$ koefisien variabel

$\mathrm{X} 1$ = Persyaratan Akuntan Publik

X2 = Kewajiban Akuntan Publik

X3 = Sanksi Akuntan Publik

X4 = Motivasi Karir

X5 = Motivasi Kualitas Diri

X6 = Motivasi Ekonomi

$\mathrm{X} 7=$ Motivasi Sosial

X7 = Minat gelar CA/CPA

$\mathrm{X} 8$ = PMK No.25 Tahun 2014

$e=$ error

\section{Uji F}

Uji statistik F pada dasarnya menunjukkan apakah semua variabel bebas yang dimasukkan dalam model mempunyai pengaruh secara bersama-sama terhadap variabel terikat (Ghozali, 2013). Pengujiannya dilakukan dengan menggunakan distribusi $F$ dengan membandingkan antara nilai kritis $\mathrm{F}\left(\mathrm{F}_{\text {tabel }}\right)$ dengan nilai Fhitung yang terdapat pada tabel Analysis of Variance dari hasil perhitungan.

Apabila $F_{\text {hitung }}<\mathrm{F}_{\text {tabel }}$, maka Ho ditolak sehingga dapat dikatan bahwa variabel bebas dari regresi dapat menerangkan variabel terikat secara serentak. Sebaliknya jika $F_{\text {hitung }}<F_{\text {tabel }}$, maka Ho diterima sehingga variabel bebas tidak perlu menjelaskan variabel terikat.

\section{Uji t}

Uji t untuk membuktikan dan mengetahui pengaruh variabel bebas secara individu terhadap variabel terikat. Uji t digunakan untuk mengetahui kemaknaan koefisien parsial. Uji ini dilakukan dengan cara membandingkan nilai statistik t dengan titik kritis menurut tabel. Apabila nilai statistik thasil perhitungan lebih tinggi dibandingkan nilai ttabel, maka kita menerima hipotesis alternatif (Ghozali, 2013).

- Ho : $\beta=0$, tidak ada pengaruh secara parsial antara variabel bebas, terhadap variabel terikat. 
- Ha : $\beta>0$, ada pengaruh positif dan signifikan secara parsial antara variabel bebas dan variabel terikat.

Dengan kriteria sebagai berikut : taraf signifikan sebesar $0,05 \%$, apabila tdihitung $<\mathrm{t}_{\text {tabel }}$ maka Ho diterima Ha ditolak, dan apabila $t$ hitung $>t_{\text {tabel }}$ maka Ho ditolak Ha diterima.

\section{Koefisien Determinasi $\left(\mathbf{R}^{2}\right)$}

Untuk mengetahui besarnya kontribusi variabel bebas dan variabel terikat, maka perlu dicari koefisien determinasi secara keseluruhan. Hasil perhitugan $\mathrm{R}^{2}$ secara keseluruhan digunakan untuk mengukur ketepatan yang paling baik dari analisis regresi linear berganda.

- Apabila $\mathrm{R}^{2}$ mendekati 1 (satu) maka dapat dikatakan semakin kuat model tersebut dalam menerangkan variasi variabel bebas terhadap variabel terikat dan,

- Sebaliknya apabila $\mathrm{R}^{2}$ mendekati 0 (nol) maka semakin lemah variasi variabel bebas dalam menerangkan variabel terikat.

\section{HASIL PENELITIAN DAN PEMBAHASAN}

\section{Statistik Deskriptif Responden}

Penelitian dilakukan di Institut dan Bisnis Informatika (IIB) Darmajaya dengan subjek penelitian mahasiswa program studi akuntansi yang masih aktif, tahun angkatan 2013-2015 atau semester 4 dan semester 6 .

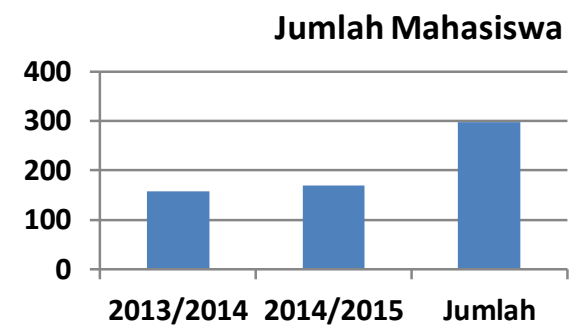

Gambar 1.1. Jumlah Mahasiswa Akuntansi Semester 4 dan 6

Untuk keperluan penelitian, sebanyak 298 disebarkan selama bulanSeptember s/d Oktober 2016 kepada mahasiswa akuntansi semester 4 dan 6 di IIB Darmajaya. Berikut rincian pengambilan Sampel yang dapat dilihat pada tabel 4.1. berikut:

Tabel 4.1. Sampel dan Respon Rate

\begin{tabular}{|l|c|c|}
\hline \multicolumn{1}{|c|}{ Keterangan } & Hasil Kuesioner & Presentase (\%) \\
\hline Kuesioner yang disebar & 298 & $100 \%$ \\
\hline Kuesioner yang tidak kembali & 53 & $18 \%$ \\
\hline Kuesioner lengkap yang dapat diolah & 184 & $62 \%$ \\
\hline Kuesioner Tidak Lengkap & 61 & $20 \%$ \\
\hline
\end{tabular}

Tabel 4.2. Semester Yang telah ditempuh Responden

\begin{tabular}{|l|c|c|}
\hline Keterangan & Hasil Kuesioner & Presentase (\%) \\
\hline Semester 4 & 167 & $68 \%$ \\
\hline Semester 6 & 78 & $32 \%$ \\
\hline Total & 245 & $100 \%$ \\
\hline
\end{tabular}


Dari 245 mahasiswa yang dijadikan responden dapat diketahui karakteristik masingmasing responden yang terdiri dari semester yang sedang ditempuh. Berdasarkan semester yang sedang ditempuh dapat diketahui bahwa responden semester 4 sebanyak 167 orang atau 68 persen dan semester 6 sebanyak 78 orang atau 32 persen.

\section{Uji Validitas dan Reliabilitas}

Untuk tingkat validitas dilakukan uji signifikansi dengan membandingkan nilai $r$ hitung dengan nilai $r$ tabel. Untuk degree of freedom $(\mathrm{df})=\mathrm{n}-\mathrm{k}$ dalam hal ini $\mathrm{n}$ adalah jumlah sampel dan $\mathrm{k}$ adalah jumlah konstruk/variabel.

Suatu kuesioner dapat dikatakan realibel atau handal jika jawaban seseorang terhadap pernyataan adalah konsisten atau stabil dari waktu ke waktu. Suatu variabel dikatakan reliable jika memberikan cronbach's alpha diatas 0,6 (Ghozali, 2013). Pengujian dilakukan dengan per indikator menggunakan pernyataan yang terdapat di dalam kuesioner. Dari pengujian dilakukan diperoleh, sebagai berikut:

Tabel 4.3. Uji Reliabilitas (X1)

Reliability Statistics

\begin{tabular}{|c|c|}
\hline Cronbach's Alpha & $\mathrm{N}$ of Items \\
\hline ,637 & 6 \\
\hline
\end{tabular}

Tabel diatas menunjukan nilai Cronbach's Alpha yang berfungsi untuk menguji reliabilitas dari 6 pertanyaan yang digunakan untuk mengukur Emphaty. Tidak ada nilai baku secara statistik untuk menentukan kriteria reliabilitas dari alat ukur, namun beberapa praktisi berpendapat bahwa pertanyaan dikatakan valid jika memiliki nilai Cronbach's Alpha > 0,6. Terlihat bahwa hasil perhitungan nilai Cronbach's Alpha mendapatkan nilai 0.637 yang menunjukan bahwa ke- 6 pertanyaan cukup reliabel.

Tabel 4.4. Validitas dan Reabilitas (X1)

Item-Total Statistics

\begin{tabular}{|l|r|r|r|r|}
\hline & $\begin{array}{c}\text { Scale Mean if } \\
\text { Item Deleted }\end{array}$ & $\begin{array}{c}\text { Scale Variance if } \\
\text { Item Deleted }\end{array}$ & $\begin{array}{c}\text { Corrected } \\
\text { Item-Total } \\
\text { Correlation }\end{array}$ & $\begin{array}{c}\text { Cronbach's } \\
\text { Alpha if } \\
\text { Item } \\
\text { Deleted }\end{array}$ \\
\hline Pertanyaan 1 & 18,7120 & 7,496 &, 221 &, 648 \\
Pertanyaan 3 & 18,5109 & 7,049 &, 339 &, 605 \\
Pertanyaan 4 & 18,6630 & 6,006 &, 519 &, 528 \\
Pertanyaan 5 & 18,6848 & 6,392 &, 496 &, 543 \\
Pertanyaan 7 & 18,6793 & 6,984 &, 388 &, 587 \\
Pertanyaan 8 & 18,3533 & 7,541 &, 253 &, 634 \\
\hline
\end{tabular}

Sumber : data diolah

Tabel Item-Total Statistics memberikan informasi mengenai uji VALIDITAS. Untuk mengetahui Item pertanyaan mana saja yang valid dilihat dari nilai korelasi yang terletak pada kolom Corrected Item-Total Correlation. Kriteria sebuah item pertanyaan dikatakan valid jika nilai KORELASI > KORELASI TABEL yang berada pada TABEL KORELASI PEARSON. Pada kasus ini besarnya df dapat dihitung 184-2 atau $\mathrm{df}=182$ dengan alpha 0,05 didapat $r$ tabel 0,1447; jika $r$ hitung (untuk tiap-tiap butir pertanyaan dapat dilihat pada kolom 
corrected item pertanyaan total correlation) lebih besar dari $r$ tabel dan nilai $r$ positif, maka butir pertanyaan tersebut dikatakan valid.

Tabel 4.5. Uji Reliabilitas (X2)

Reliability Statistics

\begin{tabular}{|r|r|}
\hline Cronbach's Alpha & N of Items \\
\hline, 637 & 3 \\
\hline
\end{tabular}

Sumber : data diolah

Tabel diatas menunjukan nilai Cronbach's Alpha yang berfungsi untuk menguji reliabilitas dari 3 pertanyaan yang digunakan untuk mengukur Emphaty. Tidak ada nilai baku secara statistik untuk menentukan kriteria reliabilitas dari alat ukur, namun beberapa praktisi berpendapat bahwa pertanyaan dikatakan valid jika memiliki nilai Cronbach's Alpha > 0,6. Terlihat bahwa hasil perhitungan nilai Cronbach's Alpha mendapatkan nilai 0.637 yang menunjukan bahwa ke- 3 pertanyaan cukup reliabel.

Tabel 4.6. Validitas dan reabilitas (X2)

Item-Total Statistics

\begin{tabular}{|l|r|r|r|r|}
\hline & $\begin{array}{c}\text { Scale Mean if } \\
\text { Item Deleted }\end{array}$ & $\begin{array}{c}\text { Scale Variance if } \\
\text { Item Deleted }\end{array}$ & $\begin{array}{c}\text { Corrected } \\
\text { Item-Total } \\
\text { Correlation }\end{array}$ & $\begin{array}{c}\text { Cronbach's } \\
\text { Alpha if } \\
\text { Item } \\
\text { Deleted }\end{array}$ \\
\hline Pertanyaan 1 & 7,3098 & 2,434 &, 339 &, 675 \\
Pertanyaan 2 & 7,4511 & 1,779 &, 552 &, 376 \\
Pertanyaan 3 & 7,4891 & 2,142 &, 460 &, 520 \\
\hline
\end{tabular}

Sumber: data diolah

Tabel Item-Total Statistics memberikan informasi mengenai uji VALIDITAS. Untuk mengetahui Item pertanyaan mana saja yang valid dilihat dari nilai korelasi yang terletak pada kolom Corrected Item-Total Correlation. Kriteria sebuah item pertanyaan dikatakan valid jika nilai KORELASI > KORELASI TABEL yang berada pada TABEL KORELASI PEARSON. Pada kasus ini besarnya df dapat dihitung 184-2 atau $\mathrm{df}=182$ dengan alpha 0,05 didapat $r$ tabel 0,1447 ; jika $r$ hitung (untuk tiap-tiap butir pertanyaan dapat dilihat pada kolom corrected itempertanyaan total correlation) lebih besar dari $\mathrm{r}$ tabel dan nilai $\mathrm{r}$ positif, maka butir pertanyaan tersebut dikatakan valid.

Tabel 4.7. Uji Reliabilitas (X3)

Reliability Statistics

\begin{tabular}{|r|r|}
\hline Cronbach's Alpha & N of Items \\
\hline, 673 & 2 \\
\hline
\end{tabular}

Sumber: data diolah

Tabel diatas menunjukan nilai Cronbach's Alpha yang berfungsi untuk menguji reliabilitas dari 2 pertanyaan yang digunakan untuk mengukur Emphaty. Tidak ada nilai baku secara statistik untuk menentukan kriteria reliabilitas dari alat ukur, namun beberapa praktisi berpendapat bahwa pertanyaan dikatakan valid jika memiliki nilai Cronbach's Alpha > 0,6. Terlihat bahwa hasil perhitungan nilai Cronbach's Alpha mendapatkan nilai 0.673 yang menunjukan bahwa ke- 2 pertanyaan cukup reliabel. 
Tabel 4.8. Validitas dan reabilitas (X3)

Item-Total Statistics

\begin{tabular}{|l|r|r|r|r|}
\hline & $\begin{array}{c}\text { Scale Mean if } \\
\text { Item Deleted }\end{array}$ & $\begin{array}{c}\text { Scale Variance if } \\
\text { Item Deleted }\end{array}$ & $\begin{array}{c}\text { Corrected } \\
\text { Item-Total } \\
\text { Correlation }\end{array}$ & $\begin{array}{c}\text { Cronbach's } \\
\text { Alpha if Item } \\
\text { Deleted }\end{array}$ \\
\hline Pertanyaan 1 & 3,5326 &, 873 &, 513 & \\
Pertanyaan 2 & 3,5652 & 1,165 &, 513 & \\
\hline
\end{tabular}

Sumber: data diolah

Tabel Item-Total Statistics memberikan informasi mengenai uji VALIDITAS. Untuk mengetahui Item pertanyaan mana saja yang valid dilihat dari nilai korelasi yang terletak pada kolom Corrected Item-Total Correlation. Kriteria sebuah item pertanyaan dikatakan valid jika nilai KORELASI > KORELASI TABEL yang berada pada TABEL KORELASI PEARSON. Pada kasus ini besarnya df dapat dihitung 184-2 atau $\mathrm{df}=182$ dengan alpha 0,05 didapat $r$ tabel 0,1447 ; jika $r$ hitung (untuk tiap-tiap butir pertanyaan dapat dilihat pada kolom corrected item pertanyaan total correlation) lebih besar dari $\mathrm{r}$ tabel dan nilai $\mathrm{r}$ positif, maka butir pertanyaan tersebut dikatakan valid.

Tabel 4.9. Uji Reliabilitas (X4)

Reliability Statistics

\begin{tabular}{|r|r|}
\hline $\begin{array}{c}\text { Cronbach's } \\
\text { Alpha }\end{array}$ & N of Items \\
\hline, 604 & 3 \\
\hline
\end{tabular}

Sumber: data diolah

Tabel diatas menunjukan nilai Cronbach's Alpha yang berfungsi untuk menguji reliabilitas dari 3 pertanyaan yang digunakan untuk mengukur Emphaty. Tidak ada nilai baku secara statistik untuk menentukan kriteria reliabilitas dari alat ukur, namun beberapa praktisi berpendapat bahwa pertanyaan dikatakan valid jika memiliki nilai Cronbach's Alpha > 0,6. Terlihat bahwa hasil perhitungan nilai Cronbach's Alpha mendapatkan nilai 0.604 yang menunjukan bahwa ke- 3 pertanyaan cukup reliabel

Tabel 4.10. Validitas dan Reabilitas (X4)

\section{Item-Total Statistics}

\begin{tabular}{|l|r|r|r|r|}
\hline & $\begin{array}{c}\text { Scale Mean if } \\
\text { Item Deleted }\end{array}$ & $\begin{array}{c}\text { Scale Variance if } \\
\text { Item Deleted }\end{array}$ & $\begin{array}{c}\text { Corrected } \\
\text { Item-Total } \\
\text { Correlation }\end{array}$ & $\begin{array}{c}\text { Cronbach's } \\
\text { Alpha if } \\
\text { Item } \\
\text { Deleted }\end{array}$ \\
\hline Pertanyaan 1 & 7,9076 & 1,330 &, 374 &, 561 \\
Pertanyaan 2 & 7,6957 & 1,098 &, 541 &, 293 \\
Pertanyaan 3 & 7,4185 & 1,534 &, 336 &, 606 \\
\hline
\end{tabular}

Sumber: data diolah

Tabel Item-Total Statistics memberikan informasi mengenai uji VALIDITAS. Untuk mengetahui Item pertanyaan mana saja yang valid dilihat dari nilai korelasi yang terletak pada kolom Corrected Item-Total Correlation. Kriteria sebuah item pertanyaan dikatakan valid jika nilai KORELASI > KORELASI TABEL yang berada pada TABEL KORELASI PEARSON. Pada kasus ini besarnya df dapat dihitung 184-2 atau $\mathrm{df}=182$ dengan alpha 0,05 
didapat $\mathrm{r}$ tabel 0,1447; jika $\mathrm{r}$ hitung (untuk tiap-tiap butir pertanyaan dapat dilihat pada kolom corrected item pertanyaan total correlation) lebih besar dari $r$ tabel dan nilai $r$ positif, maka butir pertanyaan tersebut dikatakan valid.

Tabel 4.11. Uji Reliabilitas (X5)

Reliability Statistics

\begin{tabular}{|r|c|}
\hline Cronbach's Alpha & \multicolumn{1}{c|}{$\begin{array}{c}\text { N of } \\
\text { Items }\end{array}$} \\
\hline, 743 & 3 \\
\hline
\end{tabular}

Sumber: data diolah

Tabel diatas menunjukan nilai Cronbach's Alpha yang berfungsi untuk menguji reliabilitas dari 3 pertanyaan yang digunakan untuk mengukur Emphaty. Tidak ada nilai baku secara statistik untuk menentukan kriteria reliabilitas dari alat ukur, namun beberapa praktisi berpendapat bahwa pertanyaan dikatakan valid jika memiliki nilai Cronbach's Alpha > 0,6. Terlihat bahwa hasil perhitungan nilai Cronbach's Alpha mendapatkan nilai 0.743 yang menunjukan bahwa ke- 3 pertanyaan cukup reliabel.

Tabel 4.12. Validitas dan Reabilitas (X5)

Item-Total Statistics

\begin{tabular}{|l|r|r|r|r|}
\hline & $\begin{array}{c}\text { Scale Mean if } \\
\text { Item Deleted }\end{array}$ & $\begin{array}{c}\text { Scale Variance if } \\
\text { Item Deleted }\end{array}$ & $\begin{array}{c}\text { Corrected } \\
\text { Item-Total } \\
\text { Correlation }\end{array}$ & $\begin{array}{c}\text { Cronbach's } \\
\text { Alpha if } \\
\text { Item Deleted }\end{array}$ \\
\hline Pertanyaan 1 & 6,3207 & 3,618 & $\mathbf{5 3 2}$ &, 702 \\
Pertanyaan 2 & 6,6413 & 2,745 & $\mathbf{, 7 2 0}$ &, 467 \\
Pertanyaan 3 & 6,6359 & 3,173 & $\mathbf{4 8 0}$ &, 773 \\
\hline
\end{tabular}

Sumber: data diolah

Tabel Item-Total Statistics memberikan informasi mengenai uji VALIDITAS. Untuk mengetahui Item pertanyaan mana saja yang valid dilihat dari nilai korelasi yang terletak pada kolom Corrected Item-Total Correlation. Kriteria sebuah item pertanyaan dikatakan valid jika nilai KORELASI > KORELASI TABEL yang berada pada TABEL KORELASI PEARSON. Pada kasus ini besarnya df dapat dihitung 184-2 atau $\mathrm{df}=182$ dengan alpha 0,05 didapat $r$ tabel 0,1447; jika $r$ hitung (untuk tiap-tiap butir pertanyaan dapat dilihat pada kolom corrected item pertanyaan total correlation) lebih besar dari $r$ tabel dan nilai $r$ positif, maka butir pertanyaan tersebut dikatakan valid.

Tabel 4.13. Uji Reliabilitas (X6) Reliability Statistics

\begin{tabular}{|r|r|}
\hline Cronbach's Alpha & N of Items \\
\hline $\mathbf{6 2 7}$ & 6 \\
\hline
\end{tabular}

Sumber: data diolah

Tabel diatas menunjukan nilai Cronbach's Alpha yang berfungsi untuk menguji reliabilitas dari 6 pertanyaan yang digunakan untuk mengukur Emphaty. Tidak ada nilai baku secara statistik untuk menentukan kriteria reliabilitas dari alat ukur, namun beberapa praktisi berpendapat bahwa pertanyaan dikatakan valid jika memiliki nilai Cronbach's Alpha > 0,6. Terlihat bahwa hasil perhitungan nilai Cronbach's Alpha mendapatkan nilai 0.627 yang menunjukan bahwa ke- 6 pertanyaan cukup reliabel. 
Tabel 4.14. Validitas dan Reliabilitas (X6)

\section{Item-Total Statistics}

\begin{tabular}{|l|r|r|r|r|}
\hline & $\begin{array}{c}\text { Scale Mean if } \\
\text { Item Deleted }\end{array}$ & $\begin{array}{c}\text { Scale } \\
\text { Variance if } \\
\text { Item Deleted }\end{array}$ & $\begin{array}{c}\text { Corrected } \\
\text { Item-Total } \\
\text { Correlation }\end{array}$ & $\begin{array}{c}\text { Cronbach's } \\
\text { Alpha if } \\
\text { Item Deleted }\end{array}$ \\
\hline Pertanyaan 1 & 18,4293 & 7,383 & $\mathbf{, 2 6 7}$ &, 614 \\
Pertanyaan 2 & 18,9728 & 5,808 & $\mathbf{, 5 4 2}$ &, 505 \\
Pertanyaan 3 & 18,2554 & 7,262 & $\mathbf{, 2 4 4}$ &, 623 \\
Pertanyaan 4 & 18,6304 & 6,770 & $\mathbf{, 3 3 3}$ &, 592 \\
Pertanyaan 5 & 18,7065 & 6,482 & $\mathbf{, 3 1 5}$ &, 602 \\
Pertanyaan 6 & 19,1522 & 5,813 & $\mathbf{, 4 5 1}$ &, 542 \\
\hline
\end{tabular}

Sumber: data diolah

Tabel Item-Total Statistics memberikan informasi mengenai uji VALIDITAS. Untuk mengetahui Item pertanyaan mana saja yang valid dilihat dari nilai korelasi yang terletak pada kolom Corrected Item-Total Correlation. Kriteria sebuah item pertanyaan dikatakan valid jika nilai KORELASI > KORELASI TABEL yang berada pada TABEL KORELASI PEARSON. Pada kasus ini besarnya df dapat dihitung 184-2 atau $\mathrm{df}=182$ dengan alpha 0,05 didapat $r$ tabel 0,1447; jika $r$ hitung (untuk tiap-tiap butir pertanyaan dapat dilihat pada kolom corrected item pertanyaan total correlation) lebih besar dari $r$ tabel dan nilai $r$ positif, maka butir pertanyaan tersebut dikatakan valid.

Tabel 4.15. Uji Reliabilitas (X7)

Reliability Statistics

\begin{tabular}{|r|r|}
\hline $\begin{array}{c}\text { Cronbach's } \\
\text { Alpha }\end{array}$ & N of Items \\
\hline $\mathbf{6 1 6}$ & 3 \\
\hline
\end{tabular}

Sumber: data diolah

Tabel diatas menunjukan nilai Cronbach's Alpha yang berfungsi untuk menguji reliabilitas dari 3 pertanyaan yang digunakan untuk mengukur Emphaty. Tidak ada nilai baku secara statistik untuk menentukan kriteria reliabilitas dari alat ukur, namun beberapa praktisi berpendapat bahwa pertanyaan dikatakan valid jika memiliki nilai Cronbach's Alpha > 0,6. Terlihat bahwa hasil perhitungan nilai Cronbach's Alpha mendapatkan nilai 0.616 yang menunjukan bahwa ke- 3 pertanyaan cukup reliabel.

Tabel 4.16. Validitas dan reabilitas (X7)

\section{Item-Total Statistics}

\begin{tabular}{|l|r|r|r|r|}
\hline & $\begin{array}{c}\text { Scale Mean if } \\
\text { Item Deleted }\end{array}$ & $\begin{array}{c}\text { Scale Variance } \\
\text { if Item Deleted }\end{array}$ & $\begin{array}{r}\text { Corrected } \\
\text { Item-Total } \\
\text { Correlation }\end{array}$ & $\begin{array}{c}\text { Cronbach's } \\
\text { Alpha if } \\
\text { Item } \\
\text { Deleted }\end{array}$ \\
\hline Pertanyaan 1 & 7,9457 & 1,451 &, 394 &, 562 \\
Pertanyaan 2 & 7,8859 & 1,522 &, 359 &, 610 \\
Pertanyaan 3 & 7,9837 & 1,382 &, 532 &, 366 \\
\hline
\end{tabular}


Tabel 4.17. Uji Reliabilitas (X8)

Reliability Statistics

\begin{tabular}{|r|r|}
\hline Cronbach's Alpha & N of Items \\
\hline $\mathbf{, 6 3 6}$ & 3 \\
\hline
\end{tabular}

Sumber: data diolah

Tabel diatas menunjukan nilai Cronbach's Alpha yang berfungsi untuk menguji reliabilitas dari 3 pertanyaan yang digunakan untuk mengukur Emphaty. Tidak ada nilai baku secara statistik untuk menentukan kriteria reliabilitas dari alat ukur, namun beberapa praktisi berpendapat bahwa pertanyaan dikatakan valid jika memiliki nilai Cronbach's Alpha > 0,6. Terlihat bahwa hasil perhitungan nilai Cronbach's Alpha mendapatkan nilai 0.636 yang menunjukan bahwa ke- 3 pertanyaan cukup reliabel.

Tabel 4.18. Validitas dan Reliabilitas (X8)

Item-Total Statistics

\begin{tabular}{|l|r|r|r|r|}
\hline & $\begin{array}{c}\text { Scale Mean if } \\
\text { Item Deleted }\end{array}$ & $\begin{array}{c}\text { Scale Variance if } \\
\text { Item Deleted }\end{array}$ & $\begin{array}{c}\text { Corrected } \\
\text { Item-Total } \\
\text { Correlation }\end{array}$ & $\begin{array}{c}\text { Cronbach's } \\
\text { Alpha if } \\
\text { Item } \\
\text { Deleted }\end{array}$ \\
\hline Pertanyaan 1 & 8,3750 &, 990 &, 478 &, 492 \\
Pertanyaan 2 & 8,1685 & 1,026 &, 563 &, 378 \\
Pertanyaan 3 & 8,4130 & 1,238 &, 315 &, 708 \\
\hline
\end{tabular}

Sumber: data diolah

Tabel Item-Total Statistics memberikan informasi mengenai uji VALIDITAS. Untuk mengetahui Item pertanyaan mana saja yang valid dilihat dari nilai korelasi yang terletak pada kolom Corrected Item-Total Correlation. Kriteria sebuah item pertanyaan dikatakan valid jika nilai KORELASI > KORELASI TABEL yang berada pada TABEL KORELASI PEARSON. Pada kasus ini besarnya df dapat dihitung 184-2 atau $\mathrm{df}=182$ dengan alpha 0,05 didapat $\mathrm{r}$ tabel 0,1447 ; jika $\mathrm{r}$ hitung (untuk tiap-tiap butir pertanyaan dapat dilihat pada kolom corrected item pertanyaan total correlation) lebih besar dari $r$ tabel dan nilai $r$ positif, maka butir pertanyaan tersebut dikatakan valid.

Tabel 4.19. Uji Reliabilitas (X9)

Reliability Statistics

\begin{tabular}{|r|r|}
\hline Cronbach's Alpha & N of Items \\
\hline $\mathbf{6 0 2}$ & 4 \\
\hline
\end{tabular}

Sumber: data diolah

Tabel diatas menunjukan nilai Cronbach's Alpha yang berfungsi untuk menguji reliabilitas dari 4 pertanyaan yang digunakan untuk mengukur Emphaty. Tidak ada nilai baku secara statistik untuk menentukan kriteria reliabilitas dari alat ukur, namun beberapa praktisi berpendapat bahwa pertanyaan dikatakan valid jika memiliki nilai Cronbach's Alpha > 0,6. Terlihat bahwa hasil perhitungan nilai Cronbach's Alpha mendapatkan nilai 0.636 yang menunjukan bahwa ke- 4 pertanyaan cukup reliabel. 
Tabel 4.20. Validitas dan Reliabilitas (X9)

Item-Total Statistics

\begin{tabular}{|l|r|r|r|r|}
\hline & $\begin{array}{c}\text { Scale Mean if } \\
\text { Item Deleted }\end{array}$ & $\begin{array}{c}\text { Scale Variance } \\
\text { if Item Deleted }\end{array}$ & $\begin{array}{c}\text { Corrected } \\
\text { Item-Total } \\
\text { Correlation }\end{array}$ & $\begin{array}{c}\text { Cronbach's } \\
\text { Alpha if Item } \\
\text { Deleted }\end{array}$ \\
\hline Pertanyaan 1 & 11,2446 & 2,885 &, 474 &, 452 \\
Pertanyaan 2 & 11,2663 & 2,951 &, 541 &, 401 \\
Pertanyaan 3 & 11,2609 & 3,691 &, 305 &, 585 \\
Pertanyaan 4 & 10,9348 & 3,930 &, 227 &, 636 \\
\hline
\end{tabular}

Sumber: data diolah

Tabel Item-Total Statistics memberikan informasi mengenai uji VALIDITAS. Untuk mengetahui Item pertanyaan mana saja yang valid dilihat dari nilai korelasi yang terletak pada kolom Corrected Item-Total Correlation. Kriteria sebuah item pertanyaan dikatakan valid jika nilai KORELASI > KORELASI TABEL yang berada pada TABEL KORELASI PEARSON. Pada kasus ini besarnya df dapat dihitung 184-2 atau df $=182$ dengan alpha 0,05 didapat $r$ tabel 0,1447; jika $r$ hitung (untuk tiap-tiap butir pertanyaan dapat dilihat pada kolom corrected item pertanyaan total correlation) lebih besar dari $r$ tabel dan nilai $r$ positif, maka butir pertanyaan tersebut dikatakan valid.

Tabel 4.21. Uji Reliabilitas (Y)
Reliability Statistics
\begin{tabular}{|r|r|}
\hline Cronbach's Alpha & N of Items \\
\hline $\mathbf{7 4 0}$ & 6 \\
\hline
\end{tabular}

Sumber: data diolah

Tabel diatas menunjukan nilai Cronbach's Alpha yang berfungsi untuk menguji reliabilitas dari 6 pertanyaan yang digunakan untuk mengukur Emphaty. Tidak ada nilai baku secara statistik untuk menentukan kriteria reliabilitas dari alat ukur, namun beberapa praktisi berpendapat bahwa pertanyaan dikatakan valid jika memiliki nilai Cronbach's Alpha > 0,6. Terlihat bahwa hasil perhitungan nilai Cronbach's Alpha mendapatkan nilai 0.740 yang menunjukan bahwa ke-6 pertanyaan cukup reliabel.

Tabel 4.22. Validitas dan Reliabilitas (X9)

Item-Total Statistics

\begin{tabular}{|l|r|r|r|r|}
\hline & $\begin{array}{c}\text { Scale Mean if } \\
\text { Item Deleted }\end{array}$ & $\begin{array}{c}\text { Scale Variance if } \\
\text { Item Deleted }\end{array}$ & $\begin{array}{c}\text { Corrected } \\
\text { Item-Total } \\
\text { Correlation }\end{array}$ & $\begin{array}{c}\text { Cronbach's } \\
\text { Alpha if Item } \\
\text { Deleted }\end{array}$ \\
\hline Pertanyaan 1 & 18,8533 & 7,809 &, 418 &, 723 \\
Pertanyaan 2 & 18,8750 & 7,793 &, 492 &, 698 \\
Pertanyaan 3 & 18,8696 & 7,895 &, 519 &, 691 \\
Pertanyaan 4 & 18,5435 & 8,162 &, 460 &, 707 \\
Pertanyaan 5 & 18,8696 & 7,895 &, 519 &, 691 \\
Pertanyaan 6 & 18,5435 & 8,162 &, 460 &, 707 \\
\hline
\end{tabular}

Sumber: data diolah

Tabel Item-Total Statistics memberikan informasi mengenai uji VALIDITAS. Untuk mengetahui Item pertanyaan mana saja yang valid dilihat dari nilai korelasi yang terletak pada kolom Corrected Item-Total Correlation. Kriteria sebuah item pertanyaan dikatakan 
valid jika nilai KORELASI > KORELASI TABEL yang berada pada TABEL KORELASI PEARSON. Pada kasus ini besarnya df dapat dihitung 184-2 atau df $=182$ dengan alpha 0,05 didapat $r$ tabel 0,1447; jika $r$ hitung (untuk tiap-tiap butir pertanyaan dapat dilihat pada kolom corrected item pertanyaan total correlation) lebih besar dari $r$ tabel dan nilai $r$ positif, maka butir pertanyaan tersebut dikatakan valid.

\section{Uji Normalitas}

Untuk mengetahui apakah dalam model regresi variabel dependen dan independen keduanya mempunyai distribusi normal atau tidak, dapat dilakukan dengan uji normalitas. Model regresi yang baik adalah yang memiliki distribusi normal/mendekati normal.

Tabel 4.23. Uji Normalitas Data

One-Sample Kolmogorov-Smirnov Test

\begin{tabular}{|ll|r|}
\hline & & Unstandardized Residual \\
\hline $\mathrm{N}$ & & 184 \\
Normal Parameters & a,b & Mean \\
& Std. Deviation & $0 \mathrm{E}-7$ \\
Most Extreme & Absolute &, 11692005 \\
Differences & Positive &, 060 \\
& Negative &, 060 \\
Kolmogorov-Smirnov Z &,- 042 \\
Asymp. Sig. (2-tailed) &, 816 \\
\hline
\end{tabular}

Sumber: data diolah

a. Test distribution is Normal.

b. Calculated from data.

Berdasarkan hasil uji normalitas data diperoleh nilai z sebesar 0,816 dengan probabilitas 0,518, karena nilai probabilitas dengan signifikansi lebih besar dari 0,05 maka data berdistribusi normal dan dilanjutkan uji hipotesis dengan multiple regression.

\section{Analisis Data}

\section{Analisis Regresi Linier Berganda}

Tabel 4.24. Analisis Regresi Linier Berganda

Coefficients $^{\mathrm{a}}$

\begin{tabular}{|l|r|r|r|r|r|}
\hline Model & \multicolumn{2}{|c|}{$\begin{array}{c}\text { Unstandardized } \\
\text { Coefficients }\end{array}$} & $\begin{array}{r}\text { Standardized } \\
\text { Coefficients }\end{array}$ & \multicolumn{1}{c|}{ T } & \multirow{2}{*}{ Sig. } \\
\cline { 2 - 4 } & \multicolumn{1}{c|}{ B } & Std. Error & \multicolumn{1}{c|}{ Beta } & & \\
\hline \multirow{2}{*}{ (Constant) } &, 533 &, 160 & & 3,335 &, 001 \\
profesi AP &, 050 &, 051 &, 047 &, 991 &, 323 \\
Motivasi Karir &,- 028 &, 016 &,- 034 & $-1,761$ &, 080 \\
motivasi ekonomi &,- 031 &, 010 &,- 050 & $-3,028$ &, 003 \\
motivasi kualitas &,- 011 &, 017 &,- 010 &,- 618 &, 538 \\
motivasi sosial &,- 015 &, 011 &,- 023 & $-1,393$ &, 165 \\
minat Ap &, 017 &, 019 &, 015 &, 905 &, 367 \\
Hak &,- 005 &, 016 &,- 005 &,- 287 &, 774 \\
Kewajiban &,- 020 &, 019 &,- 017 & $-1,051$ &, 295 \\
Sanksi &, 905 &, 044 &, 946 & 20,465 &, 000 \\
\hline
\end{tabular}

a. Dependent Variable: PMK

Sumber: data diolah 
Regresi Linier Berganda Berdasarkan hasil analisis diatas, maka terdapat persamaan regresi linier berganda, yaitu :

$\mathrm{Y}=0.533+0.50 \mathrm{AP}-0.28 \mathrm{MK}-0.31 \mathrm{ME}-0.11 \mathrm{MK}-0.15 \mathrm{MS}+0.17 \mathrm{mAP}-0.05 \mathrm{Hak}-$ 0.020 Kewajiban +0.905 Sanksi + e

Dari persamaan regresi linier berganda diatas diperoleh nilai konstanta sebesar 0.533 Artinya, jika variabel Minat menjadi Akuntan Publik (Y) tidak dipengaruhi oleh kedua variabel bebasnya atau Profesi Akuntan Publik (X1), Motivasi Karir (X2), Motivasi Ekonomi (X3), Motivasi Kualitas (X4), Motivasi Sosial (X5), Minat menjadi Akuntan Publik (X6), Hak Akuntan Publik (X7), Kewajiban Akuntan Publik (X8), dan Sanksi Akuntan Publik (X9) bernilai nol, maka variabel Y akan Konstan sebesar 0.533. Nilai koefisien regresi pada variabel-variabel bebasnya menggambarkan apabila diperkirakan variabel bebasnya naik sebesar satu unit dan nilai variabel bebas lainnya diperkirakan konstan atau sama dengan nol, maka nilai variabel terikat diperkirakan bisa naik atau bisa turun sesuai dengan tanda koefisien regresi variabel bebasnya.

\section{Uji Koefisien Determinasi $\left(\mathbf{R}^{2}\right)$}

Analisis koefisien determinasi dilakukan untuk mengetahui seberapa besar nilai prosentase kontribusi variabel bebas Pengaruh Undang - Undang Akuntan Publik terhadap minat mahasiswa akuntansi di perguruan tinggi IIB Darmajaya menjadi Akuntan Publik). Dari hasil perhitungan didapatkan nilai koefisien determinasi sebagai berikut.

Tabel 4.25. Koefisien Determinasi $\left(\mathrm{R}^{2}\right)$

\section{Model Summary ${ }^{b}$}

\begin{tabular}{|l|c|r|r|r|}
\hline Model & R & R Square & Adjusted R Square & Std. Error of the Estimate \\
\hline 1 &, $977^{\mathrm{a}}$ &, 955 &, 952 &, 11991 \\
\hline
\end{tabular}

\section{Sumber : data diolah}

a. Predictors: (Constant), sanksi, hak, motivasi sosial, motivasi ekonomi, motivasi kualitas, keawajiban, minat Ap, Motivasi Karir, profesi AP

b. Dependent Variable: PMK

Nilai koefisien determinasi adalah sebesar 0,952, hal itu berarti bahwa variasi perubahan Y dipengaruhi oleh perubahan Variabel X sebesar 95.20\%. Jadi besarnya kontribusi variabel bebas terhadap minat mahasiswa sebagai akuntan publik sebesar $95.2 \%$, sedangkan sisanya sebesar $0.08 \%$ dipengaruhi oleh faktor lain diluar penelitian ini.

\section{Uji F}

Uji hipotesis ( Uji F ) antara variabel bebas dalamhal ini Motivasi mahasiswa akuntansi di IIB Darmajaya terhadap Undang-Undang Akuntan Publik terhadap minat menjadi akuntan publik terhadap. Hasil analisis uji $\mathrm{F}$ dapat dilihat dalam tabel berikut ini :

Tabel 4.26. Uji F

ANOVA $^{\mathrm{a}}$

\begin{tabular}{|l|r|r|r|r|l|}
\hline Model & Sum of Squares & \multicolumn{1}{c|}{ df } & Mean Square & F & Sig. \\
\hline \multirow{4}{*}{1 Regression } & 52,831 & 9 & 5,870 & 408,288 &, $000^{\mathrm{b}}$ \\
Residual & 2,502 & 174 &, 014 & & \\
Total & 55,333 & 183 & & & \\
\hline
\end{tabular}

Sumber: data diolah

a. Dependent Variable: PMK

b. Predictors: (Constant), sanksi, hak, motivasi sosial, motivasi ekonomi, motivasi kualitas, keawajiban, minat Ap, Motivasi Karir, profesi AP 
Hasil perhitungan dengan menggunakan progam SPSS dapat diketahui bahwa $\mathrm{F}$ hitung 408.288 dengan nilai probabilitas sebesar 0,000. Sehingga dapat disimpulkan bahwa variabel $\mathrm{X}$ berpengaruh secara (bersama-sama) terhadap minat mahasiswa akuntansi.

\section{KESIMPULAN}

\section{Simpulan}

Berdasarkan hasil penelitian di atas, kesimpulan yang dapat diambil adalah:

1. Impementasi UU Akuntan Publik terbukti berpengaruh terhadap minat menjadi akuntan publik.

2. Secara simultan Syarat, Kewajiban, Motivasi dan Gelar CA dan CPA dan Sanksi menjadi Akuntan Publik memiliki dampak yang terhadap Minat Mahasiswa Akuntansi untuk menjadi Akuntan Publik, karena regulasi mengatur secara jelas profesi Akuntan Publik. Dengan adanya sanksi yang tegas dalam peraturan perundangan maka setiap orang akan berusaha mematuhinya.

3. Keberadaan UU Akuntan Publik menjadikan kedudukan, hak dan kewajiban Akuntan Publik menjadi semakin jelas.dan terhormat sehingga implementasi UU tersebut telah mendorong minat mahasiswa untuk berkarir menjadi akuntan publik.

4. Persyaratan dan Kewajiban menjadi Akuntan Publik tidak memiliki pengaruh signifikan terhadap Minat mahasiswa Akuntansi untuk menjadi Akuntan Publik. Kewajiban menjadi Akuntan Publik memiliki hubungan negatif terhadap minat mahasiswa Akuntansi untuk menjadi Akuntan Publik karena mahasiswa yang memiliki keinginan untuk menjadi Akuntan Publik harus menjunjung tinggi profesionalisme terhadap profesi Akuntan Publik.

\section{Saran}

Adapun saran yang dapat diberikan adalah sebagai berikut:

1. Dengan diperolehnya hasil penelitian yang menunjukkan bahwa masih minimnya pemahaman mahasiswa terkait implementasi UU Akuntan Publik, maka disarankan kepada pimpinan Jurusan Akuntansi maupun dosen pengampu mata kuliah auditing untuk mensosialisasikan UU tersebut.

2. Penelitian ini terbatas hanya pada mahasiswa di Jurusan Akuntansi IIB Darmajaya kepada peneliti mendatang disarankan dapat memperluas objek penelitian sehingga mampu mengeneralisir dampak implementasi UU Akuntan Publik.

\section{DAFTAR PUSTAKA}

Arens, A. A., R. J. Elder, dan M. S. Beasley. (2013). Auditing and Assurance Service An Integrated Approach, 15th Edition. England: Pearson Education Limited.

Campell J.P,et al. (1970). Manajerial Behavior, performance and effectiveness. Mc. Graw Hill Coy. New York.

Cokroaminoto (2007). Membangun Kinerja Staff. Diakses tanggal 20 Mei 2016 dari : http://cokroaminoto.wordpress.com/2007/05/27/membangun-kinerja-karyawanmelaluiperbaikan-lingkungan-kerja/

Ghozali, Imam. (2013). Aplikasi Analisis Multivariat dengan Program IBM SPSS 21. Edisi tujuh, Penerbit Universitas Diponegoro, Semarang. 
Ikatan Akuntan Publik Indonesia. (2013). Standar Pofesional Akuntan Publik. Salemba empat. Jakarta.

Ikhsan, Sukardi, et al. (2013). Dampak Implementasi Undang-Undang Akuntan Publik Terhadap Minat Menjadi Akuntan Publik Studi Kasus Mahasiswa Akuntansi Universitas Negeri Semarang. Jurnal Dinamika Akuntans, 5(2), 99-108.

Keputusan Menteri Keuangan Republik Indonesia Nomor: 423/KMK.06/2002 Tanggal 30 September 2002 Tentang Jasa Akuntan Publik.

Kurnia, Ratnawati, Sutikpo. (2014). Undang-Undang No. 5 Tahun 2011 Tentang Akuntan Publik Dan Dampaknya Terhadap Minat Mahasiswa Menjadi Akuntan Publik. Simposium Nasional Akuntansi XVII. Universitas Mataram.

Matutina, Domi C, dkk. (1993). Manajermen Personalia, PT Rineka Cipta, Jakarta.

Mulyadi. (2013). Auditing. Edisi enam. Salemba empat. Bandung.

Nelson, R. M. \& DeBacker, T. K. (2008). Achievement motivation in adolescents: The role of peer climate and best friends. Journal of Experimental Education, 76(2) 170- 189.

Peraturan Menteri Keuangan Nomor 17/PMK.01/2008 Tentang Jasa Akuntan Publik.

Peraturan Menteri Keuangan Nomor 25/ PMK 01/ 2014 Tentang Akuntan Beregister Negara.

Putro, Surono Adi. (2012). Analisis Faktor-Faktor yang Mempengaruhi Minat Mahasiswa Akuntansi Untuk Berkarir Menjadi Akuntan Publik. Skripsi. Universitas Negeri Yogyakarta.

Surat Keputusan Menteri Pendidikan Nasional Nomor 179/U/2001 Tentang Penyelenggaraan Pendidikan Profesi Akuntansi.

Simamora, Henry. (2006). Manajemen Sumber Daya Manusia. Cetakan Kedua. Yogyakarta: STIE YKPN.

Undang-Undang Nomor 8 Tahun 2011 Tentang Akuntan Publik. 